\title{
Коничева Е.М. \\ Понятие, принципы, стороны, система (уровни) и организационные формы социального партнерства в сфере труда
}

\author{
САФУ имени М.В. Ломоносова \\ (Россия, Архангельск)
}

doi: $10.18411 / l j-02-2021-209$

idsp: ljournal-02-2021-209

\begin{abstract}
Аннотация
Статья посвящена анализу трудового законодательства Российской Федерации в контексте развития различных форм социального партнерства. В ходе исследования был сделан вывод о том, что социальное партнерство выступает одной из форм согласования интересов сторон трудового договора между работником и работодателем. Способствуют развитию трудовых отношений в России различные комиссии по регулированию социально-трудовых отношений - органы социального партнерства, имеющие в соответствии с законодательством компетенцию в сфере организации коллективных переговоров а также подготовки проектов коллективных соглашений и договоров.

Ключевые слова: социальное партнерство; трудовое право; трудовой кодекс; контракт; коллективный трудовой договор.
\end{abstract}

\section{Abstract}

The article is devoted to the analysis of the labor legislation of the Russian Federation in the context of the development of various forms of social partnership. The study concluded that social partnership is one of the forms of coordination of the interests of the parties to the employment contract between the employee and the employer. The development of labor relations in Russia is promoted by various commissions for the regulation of social and labor relations - social partnership bodies that have competence in the field of organizing collective negotiations and drafting collective agreements and contracts in accordance with the legislation.

Keywords: social partnership; labor law; labor code; contract; collective labor agreement.

Законодатель определяет официальную дефиницию понятия “социальное партнерство в сфере труда" посредством Трудового кодекса Российской Федерации (далее - ТК РФ). Социальное партнерство, согласно статье 23 ТК РФ, представляет собой некую систему взаимоотношений между работниками (или их представителями), работодателями (их представителями), органами государственной власти и местного самоуправления. [2] Цель социального партнерства заключается в том, чтобы обеспечить согласование интересов участвующих сторон - работников и работодателей - по вопросам регулирования как трудовых, так и иных, непосредственно связанных с ними отношений.

А.В. Тиховодова отмечает, что система социального партнерства в России представляет систему со сложной организацией. Самоорганизация, структурированность, устойчивость, регулируемость и динамичность - это те социальные по своей природе качества, которыми характеризуется система. [8] В.А. Михеев, рассматривая дефиницию в широком смысле, отождествляет ее с некой формой общественных отношений, возникающих и развивающихся в социальнотрудовой сфере. Их назначением помимо очевидного согласования интересов сторон социального партнерства, является также защита экономических интересов работодателей и работников. Среди способов реализации целей социального 
партнерства выделяют заключение договоров и соглашений, посредством которых стороны выражают своё стремление к достижению компромисса по наиболее важным, социально и экономически ориентированным для них вопросам. [8]

Таким образом, можно сделать вывод о том, что социальное партнерство доктринально может рассматриваться с точки зрения различных подходов, однако все они сводятся к достижению целей, продиктованных общими интересами участников посредством взаимодействия в контексте социально-трудовых отношений. Также общим остается субъектный состав, однако некоторые авторы выделяют государство в качестве обобщенного субъекта правовых отношений, складывающихся в сфере социального партнерства. Можно предположить, что данная позиция продиктована тем, что основы функционирования института закреплены посредством централизованного регулирования. Также, исходя из содержания трудового законодательства, органы власти могут действовать от имени государства, тем самым отражая посредством своих действий его интересы.

Принципы социального партнерства, исходя из аксиоматики, должны отражать правовую природу института посредством формулирования основополагающих начал и ключевых положений. Более полно принципы социального партнерства закреплены в ст. 24 ТК РФ, поэтому их освещение в данной работе излишне. Однако необходимо акцентировать внимание на некоторых принципах социального партнерства, которые доктринально были отмечены как наиболее важные. Среди таковых можно назвать следующие: равноправие сторон (в отличие от трудовых отношений, предполагающих отношения власте-подчинения); учет интересов сторон; их заинтересованность в достижении консенсуса; участие в договорных отношениях; законность (стороны социального партнерства действуют в рамках актуального законодательства, а также в соответствии с подзаконными и локальными актами); добровольность принятия взаимных обязательств (в иных источниках - принцип диспозитивности); ответственность сторон за невыполнение или ненадлежащее выполнение договор. [8]

Принципы социального партнерства - это те ориентиры, которыми должны руководствоваться стороны при согласовании своих интересов. Их соблюдение позволяет обеспечить эффективное функционирование института, исключить возможность злоупотребления права субъектами, привести к благоприятным социальным и экономическим последствиям для каждого участника общественных отношений.

Согласно ст. 29 ТК РФ представительство работников вправе осуществлять профессиональные союзы и их объединения, иные профсоюзные организации, предусмотренные уставами общероссийских, межрегиональных профсоюзов, или иные представители, избираемые работниками в случаях, предусмотренных ТК РФ.

Первичная профсоюзная организация представляет интересы работников в отношениях, связанных с заключением, изменением коллективных договоров, позволяет работникам реализовывать право на участие в управлении организацией и разрешении споров, возникающих между работниками и работодателями. Работники, которые не являются членами профсоюзной организации могут защищать свои интересы посредством передачи своих полномочий на орган профсоюзной организации. Таким образом, профсоюзная организация приобретает возможности для отстаивания позиции работников во взаимоотношениях с работодателем в контексте индивидуальных трудовых и непосредственно связанных с ними отношений на условиях, которые устанавливает профсоюзная организация.

Объединение работодателей представляет собой некоммерческую организацию, которая объединяет работодателей на добровольной основе для представительства интересов и защиты прав своих членов во взаимоотношениях с профсоюзами, органами власти (на уровнях как государственном, так и местном). Федеральный закон “Об объединениях работодателей” от 27.11.2002 г. №156-Ф3 (далее - Федеральный закон 
№156) конкретизирует видовую дифференциацию подобных объединений. Они, согласно ст. 4 Федерального закона № 156, могут создаваться по территориальному (региональному и межрегиональному), отраслевому, территориально-отраслевому признакам.

Комиссии по регулированию социально-трудовых отношений - органы социального партнерства, имеющие в соответствии с законодательством компетенцию в сфере организации коллективных переговоров а также подготовки проектов коллективных соглашений и договоров. Согласно Федеральному закону “О Российской трехсторонней комиссии...” от 01.05.1999 г., в состав данного органа входят не только общероссийские объединения профсоюзов и объединения работодателей, но и Правительство Российской Федерации.

Трехсторонние комиссии - субъект ограниченной компетенции, который может быть образован на уровне региона или муниципального образования. Круг их деятельности, основным назначением которой является урегулирование споров в сфере труда, определяется законодательством соответствующего уровня. Если комиссия создана на уровне местного самоуправления, то к источникам нормативого регулирования её компетенции относятся не только акты исполнительного, но и представительного органа власти.

Последний уровень - уровень организации характеризуется образованием комиссий, занимающихся ведением коллективных договоров, подготовкой проектов коллективных договором и его заключением.

Обращаясь к тематике форм социального партнерства следует сказать, что некоторые из них ранее были озвучены в исследовании. Особое внимание среди них занимают коллективные переговоры, поскольку их социальная природа наиболее полно отвечает назначению института. Круг их деятельности включает создание проекта многостороннего договора или соглашения, содействие заключению таковых между работниками и работодателями. Следующая форма - взаимные консультации, посредством которых стороны реализуют гарантии своих прав в контексте трудовых или иных связанных с ними отношений. Консультации также могут отвечать целям совершенствования трудового законодательства, а вместе с тем других нормативноправовых актов, которые содержат нормы, связанные с сферой трудового права.

На сегодняшний день разрешение вопросов социально-экономической направленности в основном осуществляется на договорных началах с учетом положений актуального законодательства. Рассматривая социальное партнерство как явление, отражающее специфику общественных отношений, складывающихся в условиях рыночной экономики, мы можем прежде всего отметить особую правовую природу данного института. Его назначение - достижение баланса в реализации каждой из сторон социального партнерства своих экономических интересов. Социальное партнерство на данный момент составляет основу правоотношений, складывающихся не только между работниками и работодателями, но и между рядом других субъектов, позволяет более эффективно достигать консенсуса при разрешении наиболее важных вопросах как в рамках организации, так и целых отраслей деятельности, что бесспорно является признаком, присущему социальному государству. [3]

$$
* * *
$$

1. Российская Федерация. Конституция (1993). Конституция Российской Федерации [Текст] : офиц. текст. - М. : Маркетинг, 2018. - 40 с.

2. Российская Федерация. Законы. Трудовой кодекс Российской Федерации [Текст] : [федеральный закон: принят Гос. Думой 21 декабря 2001 года : одобрен Советом Федерации 26 декабря 2001 года]. - М. : "Российская газета". - № 256. - 2001 г.

3. Александрова, И.А. Социальное партнерство в системе социально-трудовых отношений Российской Федерации [Текст] / И.А. Кобылкин // Вестник БГУ. - 2010. - №14.- С. 123-125. 
4. Кузнецов, В.В., Рыбкина, М.В. Сущность и принципы социального партнёрства в сфере труда [Текст] / В.В. Кузнецов, М.В. Рыбкина // Вестник УлГТУ. - 2016. - №3 (75). С 70-73.

5. Михеев, В.А. Основы социального партнерства: теория и политика [текст] : учебник для вузов. / В.А. Михеев; Москва: Экзамен. - 2001 - 448 с.

6. Потемкин, В.К., Казаков, Д.Н. Социальное партнерство: формирование, оценка, регулирование [Текст] / В.К. Потемкин, Д.Н. Казаков // СПб.: РАЕН, 2002. С. 16.

7. Рашидова, А. И. Социальное партнерство в сфере труда как категория зрелой рыночной экономики [Текст] / А.И. Рашидова // Вопросы структуризации экономики. - 2012. - №3. С. 225226.

8. Тиховодова, А. В. Социальное партнерство: сущность, функции, особенности развития в России [Текст] / А.В. Тиховодова // Известия РГПУ им. А.И. Герцена. - 2008. - №58. С. 297- 301

\section{Коростиев А.А. \\ Базельский комитет по банковскому надзору: правотворчество и ответственность}

Дальневосточный федеральный университет (Россия, Владивосток)

doi: $10.18411 / l j-02-2021-210$

idsp: ljournal-02-2021-210

\section{Аннотация}

На разных этапах экономического развития выделялись регуляторы финансовой системы. Они отличались помимо прочего, своими уникальными функциями, а также поставленными перед ними государством и обществом задачами. В статье проводится анализ одного из таких регуляторов макроуровня - Базельского комитета. Проводится краткий анализ трех Базельских стандартов. Рассмотрено влияние Базельских соглашений на банковскую систему Российской Федерации. В результате исследования обоснованы выгоды от применения данных соглашений.

Ключевые слова: Базельский комитет по банковскому надзору, Базель I, Базель II, Базель III, Базельский стандарт, банковский надзор, банковская система, страны группы десяти (G10), мегарегулятор, пруденциальная политика, кредитный риск, собственные средства банка, пруденциальное банковское регулирование.

\section{Abstract}

At different stages of economic development, various regulators of the financial system existed. They were delivered separately from each other, with their unique capabilities. The article analyzes one of such regulators at the macro level - the Basel Committee. A brief analysis of the three Basel standards is carried out. The influence of the Basel institutions on the banking system of the Russian Federation is considered. As a result of the study, these applications are reasonably applied.

Keywords: Basel Committee on Banking Supervision, Basel I, Basel II, Basel III, Basel Standard, banking supervision, banking system, countries of the Group of Ten (G10), mega-regulator, prudential policy, credit risk, own funds of the bank, prudential banking regulation.

На сегодняшний день Базельский комитет по банковскому надзору представляет собой уникальную организацию, действующую при Банке международных расчетов. При этом он не является структурным подразделением Банка международных расчетов и действует автономно. Базельский комитет является международным финансовым мегарегулятором, осуществляющим пруденциальную политику, наряду с такими организациями, как МВФ, Совет по финансовой стабильности, Банк международных расчетов.

Базельский комитет был основан президентами центральных банков стран группы десяти (G10) в 1974 году в Базеле. По состоянию на сегодняшний день членами 